\title{
News-driven business cycles in small open economies ${ }^{\text {tr }}$
}

\author{
Güneş Kamber ${ }^{\mathrm{a}, \mathrm{b}, \mathrm{e}}$, Konstantinos Theodoridis ${ }^{\mathrm{c}}$, Christoph Thoenissen ${ }^{\mathrm{b}, \mathrm{d}, *}$ \\ a Bank for International Settlements, Hong Kong \\ ${ }^{\mathrm{b}}$ CAMA, Australia \\ ${ }^{\mathrm{c}}$ Bank of England, UK \\ ${ }^{\mathrm{d}}$ University of Sheffield, Department of Economics, Sheffield S1 4DT, UK \\ ${ }^{\mathrm{e}}$ Reserve Bank of New Zealand, New Zealand
}

\section{A R T I C L E I N F O}

\section{Article history:}

Received 11 November 2014

Received in revised form 5 October 2016

Accepted 17 December 2016

Available online 27 December 2016

\section{Jel classification:}

E32

F4

Keywords:

News shocks

Business cycles

Open economy macroeconomics

Financial frictions

VAR

\begin{abstract}
A B S T R A C T
The focus of this paper is on news-driven business cycles in small open economies. We make two significant contributions. First, we develop a small open economy model where the presence of financial frictions permits the replication of business cycle co-movements in response to news shocks. Second, we use VAR analysis to identify news shocks using data on four advanced small open economies. We find that expected shocks about the future Total Factor Productivity generate business cycle co-movements in output, hours, consumption and investment. We also find that news shocks are associated with countercyclical current account dynamics. Our findings are robust across a number of alternative identification schemes.
\end{abstract}

(c) 2017 The Authors. Published by Elsevier B.V. This is an open access article under the CC BY license (http://creativecommons.org/licenses/by/4.0/).

\section{Introduction}

Does news about future Total Factor Productivity (TFP) generate business cycles in small open economies? A long tradition in macroeconomics and some recent empirical evidence suggests that news about the future might be an important driver of the business cycle. ${ }^{1}$

\footnotetext{
is We thank the Co-Editor Giancarlo Corsetti and our referees for helpful and constructive comments. We also thank Oscar Pavlov, Ippei Fujiwara and Vincenzo Quadrini for their helpful comments, and Paul Beaudry, Deokwoo Nam and Jian Wang for sharing their code and data with us. We would also like to thank seminar participants at AMW 2013 in Canberra, CEF 2013 in Vancouver, SWIM 2014 in Auckland, MMF 2014 in Durham, ABFER 2016 in Singapore, Otago University, Victoria University of Wellington, University of Waikato, University of Hull, University of Exeter and the Bank of England. All remaining errors are the copyright of the authors. The views expressed in this paper are those of the authors and do not necessarily reflect the views of the Bank of International Settlements or the Bank of England.

* Corresponding author.

E-mail addresses: Gunes.Kamber@bis.org (G. Kamber),

Konstantinos.Theodoridis@bankofengland.co.uk (K. Theodoridis),

c.thoenissen@sheffield.ac.uk (C. Thoenissen).

1 See for instance Barsky and Sims (2011)Beaudry et al. (2011b), Beaudry and Portier (2004, 2006), Schmitt-Grohé and Uribe (2012) and Fujiwara et al. (2011) and Khan and Tsoukalas (2012).
}

There has been a lot of recent interest in incorporating this idea into modern business cycle models. One of the main challenges emerging from this literature is to develop equilibrium business cycle models that replicate data-congruent macroeconomic co-movement in response to news shocks. ${ }^{2}$ The emphasis in most of this literature, particularly on the empirical side, is on the effect of news shocks in closed economies.

In this paper, we focus on the effect of news shocks in small open economies. We make two contributions. First, we put forward a novel mechanism through which news about future TFP causes business cycles. This mechanism is based on the presence of financial frictions. Specifically, the model incorporates financial frictions à la Jermann and Quadrini (2012) into an otherwise canonical small open economy model. The financial friction in this model arises because firms need to arrange a working capital loan prior to production taking place. Access to finance is constrained by the firm's net wealth position. News shocks interact with the financial friction by relaxing the borrowing constraint faced by firms. This allows firms

\footnotetext{
2 See for instance Beaudry and Portier (2004, 2007), Jaimovich and Rebelo (2009) and Beaudry et al. (2011a).
} 
to increase their demand for labour, which raises output and investment in anticipation of future increases in TFP. Greater investment and labour input today creates the expectation of higher dividends in the future, thus raising the share price in anticipation of future TFP.

Our second contribution is to identify and analyse the effects of news shock in a set of advanced small open economies. Specifically, we identify the dynamic macroeconomic effects of news shocks in four developed small open economies: Australia, Canada, New Zealand and the United Kingdom. The way news shocks are identified in the data is informed by the theoretical impulse responses of the model. In particular, our identification strategy, based on Beaudry et al. (2011b), imposes model consistent restrictions on the path of TFP, share prices and consumption. For TFP, this implies that news arrives not one, as is the convention in the literature, but two periods in advance. We also impose a restriction that at the end of the news horizon, TFP actually increases for a number of periods. Consistent with our model, we restrict share prices and consumption to rise in response to news.

We find consistent evidence that news shocks generate business cycles. As in our theoretical model, a news shock leads to positive co-movement between GDP, hours worked and investment as well as a counter-cyclical trade balance. Our results are robust across a number of alternative identification schemes, including an augmented Barsky and Sims (2011) identification. ${ }^{3}$ To our knowledge, this is the first account of the effect of news shocks in advanced small open economies.

The next section puts our contribution into the context of the literature analysing news shocks. We document the theoretical model and the transmission of the news shocks in Section 3 and 4. Section 5 and 6 present data and our preferred shock identification mechanism. In Section 7 we present our empirical results and perform a number of robustness tests around our baseline identification of news shocks. Further sensitivity analysis is reported in the online appendix to this paper.

\section{Literature and model choice}

News shocks in a standard open economy real business cycle model do not generate news-driven business or Pigou cycles. In this class of model, news about a future TFP improvement creates a positive wealth effect that raises both household consumption and leisure, thus reducing the supply of labour. In the absence of an actual increase in TFP, labour demand remains unchanged and as a result output falls in response to news.

Jaimovich and Rebelo $(2008,2009)$ show that when preferences are such that the wealth effect on labour is small, hours worked do not decline following a news shock. Eliminating the wealth effect on hours is, however, not enough to generate an actual increase in labour demand when an increase in TFP is anticipated but not yet realised. Jaimovich and Rebelo (2009) show that in a closed economy setting, this can be achieved by a combination of investment adjustment costs and variable capital utilisation. The presence of investment adjustment costs causes firms to bring the anticipated increase in future investment, associated with the increase in future TFP, forward into the current period. In a closed economy model, the hump shaped response of investment causes current period Tobin's q to fall, which in turn raises the rate at which firms utilise capital. The rise in capital utilisation raises the marginal product and thus the demand for labour. This is enough to generate new-driven business cycles.

For a small open economy, the challenge of generating newsdriven business cycles is slightly different. With real interest rates

\footnotetext{
3 We report results for this identification scheme in the online appendix.
}

determined abroad, Tobin's q always rises following a news shock. As a result, adding variable capital utilisation does not help generate business cycles in response to news shocks. Jaimovich and Rebelo (2008) show that adding labour adjustment costs that penalise large changes in labour input, will cause firms to bring forward into the current period some of the expected future increase in labour demand. ${ }^{4}$

Our modelling approach relies not on costly adjustment in the labour market, but on a simple form of financial friction to increase the demand for labour following news about future TFP. This friction introduces a wedge between the marginal product of labour and the real wage. Following Jermann and Quadrini (2012), we assume that because of limited enforcement of financial contracts, firms face an enforcement constraint on working capital loans. Because firms have to borrow the wage bill, the 'tightness' of the enforcement constraint creates a wedge between the marginal product of labour and the real wage. In our model, good news about future TFP relaxes the enforcement constraint and increases the demand for labour.

The intuition behind our results is similar to Pavlov and Weder (2013) who consider a model with counter-cyclical mark-ups. In their model, mark-ups create a wedge between the marginal product of labour and the real wage. A news shock that lowers the mark-up also reduces the labour wedge, raising firms' labour demand.

Related to our analysis is Walentin (2012), who examines news shocks in a model with limited enforcement where firms face a collateral constraint when securing external finance. As in our model, the arrival of news relaxes the borrowing constraint and raises share prices, which leads to an accelerator type effect on investment. The key difference between our approach and that of Walentin (2012) is that in our model, the firm faces the enforcement constraint on working capital, whereas in Walentin (2012), the loan is intertemporal. Financial frictions impact the business cycle via an accelerator type mechanism. This difference between our approaches matters, because only in our case does the financial friction create the aforementioned labour wedge that is helpful in generating a positive co-movement between consumption and hours. ${ }^{5}$

The literature on news shocks to TFP can be seen as being part of a wider literature on the transmission of total factor productivity shocks. Both news shocks and highly persistent, but contemporaneous, shocks to TFP have an expectations as well as a supply component. In the initial response to a news shock about TFP, the transmission mechanism is dominated by the expectations component of the shock. In a highly persistent shock to TFP, the initial transmission mechanism is affected by both the expectations as well as the supply component. In many dimensions, news and highly persistent shocks may be expected to have similar effects on the economy.

In the context of emerging market economies, Aguiar and Gopinath (2007) highlight the importance of highly persistent TFP fluctuations that are akin to shocks to trend growth. These kinds of shocks help explain the somewhat non-standard business cycle fluctuations of emerging market economies. Even for developed economies with 'standard' international business cycle characteristics, Corsetti et al. (2008a) show that highly persistent productivity shocks can bring a fairly standard international real business cycle model much closer to the data. In particular, the expectations component of highly persistent TFP shocks creates a wealth effect

\footnotetext{
4 The literature offers several alternatives to overcome the negative co-movement between consumption and hours in response to news. See among others Beaudry and Portier (2004) and Den Haan and Kaltenbrunner (2009) for closed economy approaches and Beaudry et al. (2011a) and Den Haan and Lozej (2010) for open economy approaches.

5 In Walentin (2012), a positive response of labour to news shocks requires a relatively large degree of habit persistence in hours, in addition to the financial friction.
} 
which helps the model achieve plausible degrees of international risk sharing.

Corsetti et al. (2008b) and Corsetti et al. (2014) identify TFP shocks using either long-run and sign restrictions, respectively. In both studies, the US real exchange rate is found to appreciate following a persistent increase in US TFP. Importantly, this real appreciation is not linked to the familiar Balassa-Samuelson mechanism, as both the real exchange rate and the terms of trade are shown to appreciate. In a context of a simple two-good international real business cycle model, this finding is reminiscent of a response to a shock with a significant expectations component.

Research by Nam and Wang (2015) lends credence to this view. They use an identification method that divides TFP shocks into a contemporaneous as well as an anticipated, or news, component. When separating the expectations from the supply component of a TFP shock, the authors find that for the US economy, anticipated TFP shocks are associated with a real appreciation, whereas contemporaneous shocks are linked to a depreciation.

Whereas the empirical literature on the transmission mechanism of contemporaneous TFP shocks in open economies is well advanced, the empirical literature on in the transmission mechanism of news shocks in open economies, to which our paper is a contribution, is not. There are two notable exceptions. The aforementioned Nam and Wang (2015), who focus exclusively on the US economy and a recent paper by Fratzscher and Straub (2013). The latter authors use a canonical two-country new Keynesian model in which news shocks are used to identify changes in asset prices that are not related to current fundamentals. Related to our work, they analyse asset price shocks in small open economies, including the four in our sample. However, since the focus of their work is on asset price shocks, no effort is made to properly identify news-driven business cycles. Indeed, their baseline model shows a decline in investment following a news shock, and their empirical work does not report the response of investment or employment. In contrast, we identify news shocks as shocks that raise the share price as well as lead to a path of TFP that is consistent with news about future total factor productivity. We use the thus identified shock to check whether news shocks can be a candidate driver of the business cycle and generate business cycle consistent co-movements among macroeconomic aggregates.

\section{A simple small open economy model with financial frictions}

We extend the flexible price version of the model presented in Jermann and Quadrini (2012) into a small open economy setting. To turn a closed economy real business cycle model into a small open economy model requires only a few changes to be made to the structure of the model. In an open economy, the savings of households do not have to equal the borrowing by firms. The gap between savings and investment equals the current account balance. Unlike a closed economy, the gross or pre-tax interest rate faced by households and firms is exogenous in a small open economy setting. This rate is determined instead by the world interest rate as well as a small risk premium to ensure a well defined steady state. ${ }^{6}$ Firms and households produce and consume a homogeneous good. This good is a perfect substitute for output produced in the rest of the world. As a result, the terms of trade defined as the price of imports relative to exports are constant. We make the one-good assumption for two reasons. First, abstracting from terms of trade movements allows us to focus more clearly on the role of financial frictions in the transmission of news shocks. Second, for commodity producers such as Australia, Canada and New Zealand, assuming an exogenous terms

\footnotetext{
6 See Schmitt-Grohe and Uribe (2003) for alternative ways to close small open economy models.
}

of trade is quite realistic, although this is probably not the case for the UK.

As in Jermann and Quadrini (2012), we introduce financial frictions into the environment in which domestic firms are operating. The household sector, on the other hand, faces a standard optimisation problem.

\subsection{Borrowing constrained firms}

At any time $t$, the representative firm combines hired labour, $n_{t}$ and accumulated capital stock, $k_{t-1}$ in a Cobb-Douglas production function $F\left(z_{t}, k_{t-1}, n_{t}\right)=z_{t} k_{t-1}^{\alpha} n_{t}^{1-\alpha}$. The variable $z_{t}$ denotes the level of TFP. TFP is affected by both unanticipated and anticipated shocks and evolves as follows:

$\ln z_{t}=\rho_{z} \ln z_{t-1}+\varepsilon_{z, t}+\varepsilon_{n e w s, t-j}$

Capital accumulation is subject to investment adjustment costs of the type proposed by Christiano et al. (2005)

$k_{t}=(1-\delta) k_{t-1}+i_{t}\left(1-\frac{\phi}{2}\left(\frac{i_{t}}{i_{t-1}}-1\right)^{2}\right)$

where $i_{t}$ is investment, $\delta$ the depreciation rate of capita and $\phi$ a parameter capturing the curvature of the adjustment cost function.

As in Jermann and Quadrini (2012), firms can finance investment projects either by issuing equity, $d_{t}$, or debt, $b_{t}^{f}$. Reducing equity payouts to finance investment projects does not affect a firm's tax liabilities in the same way as issuing new debt. As a result, firms prefer debt to equity finance in this model. This preference for debt finance is captured by a constant tax benefit, or subsidy. The effective interest rate faced by firms is $R_{t}=1+r_{t}(1-\tau)$, where $r_{t}$ is the world rate of interest (adjusted by a net-debt elastic risk premium) and $\tau$ captures the tax benefit on debt issuance.

The firm has to make its payments to its workers, shareholders, and creditors, as well as undertake investment before revenues are realised. To cover this cash flow mismatch, the firm has to secure an intra-temporal working capital loan equal to its production at the beginning of the period. After receiving the working capital loan, the firm can either pay its factors of production, produce and pay back the inter-temporal loan at the end of the period, or it can choose not to produce, abscond with the loan and default. To rule out the latter scenario, the firm is subject to the following enforcement constraint:

$\xi\left(k_{t}-\frac{b_{t}^{f}}{1+r_{t}}\right)=F\left(z_{t}, k_{t-1}, n_{t}\right)$

where $\xi$ denotes the probability that the lender can recover the full value of the firm's capital stock in the case of a default.

A key feature that determines the effect of this enforcement constraint on the model economy is an assumed rigidity affecting the substitution between equity and debt. If we define total intra-temporal borrowing, $l_{t}$, as:

$l_{t}=F\left(z_{t}, k_{t-1}, n_{t}\right)=w_{t} n_{t}+i_{t}+d_{t}+b_{t-1}^{f}-\frac{b_{t}^{f}}{R_{t}}$

then the firm will always be able to keep the demand for intra-period loans, $l_{t}$, constant simply by changing the composition between debt and equity finance. In this case, shocks that affect the firm's ability to borrow intra-temporally will have no effect on the firm's choice of labour input or investment. To make sure the enforcement 
constraint is binding, we introduce a cost of adjusting equity payouts, as suggested by Jermann and Quadrini (2012)

$\varphi\left(d_{t}\right)=d_{t}+\kappa\left(d_{t}-\bar{d}\right)^{2}$

where $\kappa$ a positive adjustment cost parameter and $\bar{d}$ is the steady state level of dividend payouts. Given these adjustment costs, the firm's budget constraint can be written as:

$F\left(z_{t}, k_{t-1}, n_{t}\right)-w_{t} n_{t}-i_{t}-b_{t-1}^{f}+\frac{b_{t}^{f}}{R_{t}}-\varphi\left(d_{t}\right)=0$

The firm's optimisation problem consists of maximising equity payouts, subject to the budget (5), capital accumulation (2) and enforcement (3) constraints. The first order conditions for the optimal choice of labour, inter-temporal borrowing, capital and investment are:

$\left(1-\Delta_{t} \varphi^{\prime}\left(d_{t}\right)\right) F_{n, t}=w_{t}$

$E_{t} \beta \frac{\lambda_{t+1}}{\lambda_{t}} \frac{\varphi^{\prime}\left(d_{t}\right)}{\varphi^{\prime}\left(d_{t+1}\right)} R_{t}+\Delta_{t} \varphi^{\prime}\left(d_{t}\right) \frac{R_{t}}{1+r_{t}} \xi=1$

$E_{t} \beta \frac{\lambda_{t+1}}{\lambda_{t}} \frac{\varphi^{\prime}\left(d_{t}\right)}{\varphi^{\prime}\left(d_{t+1}\right)}\left(F_{k, t}\left(1-\Delta_{t+1} \varphi^{\prime}\left(d_{t+1}\right)\right)+Q_{t+1}(1-\delta)\right)+\Delta_{t} \varphi^{\prime}\left(d_{t}\right) \xi=Q_{t}$

$$
\begin{aligned}
& Q_{t}\left(1-\frac{\phi}{2}\left(\frac{i_{t}}{i_{t-1}}-1\right)-\phi\left(\frac{i_{t}}{i_{t-1}}-1\right) \frac{i_{t}}{i_{t-1}}\right) \\
& \quad+E_{t} \beta Q_{t+1} \frac{\lambda_{t+1}}{\lambda_{t+}} \frac{\varphi^{\prime}\left(d_{t}\right)}{\varphi^{\prime}\left(d_{t+1}\right)} \phi\left(\frac{i_{t+1}}{i_{t}}-1\right)\left(\frac{i_{t+1}}{i_{t}}\right)^{2}=1
\end{aligned}
$$

The variable $\lambda_{t}$ denotes the marginal utility of consumption of households, who are the owners of the firm. The variables $q_{t}, v_{t}$ and $\mu_{t}$ are the Lagrange multipliers on constraints (5), (2) and (3), respectively. These shadow prices are used to define the following composite variables: $Q_{t}=\frac{v_{t}}{\lambda_{t}} \varphi^{\prime}\left(d_{t}\right), \Delta_{t}=\frac{\mu_{t}}{\lambda_{t}}$, and $\frac{\lambda_{t}}{\varphi^{\prime}\left(d_{t}\right)}=q_{t}$.

Because changing its financial structure is costly, the effective discount factor of the firm $\beta \frac{\lambda_{t+1}}{\lambda_{t}} \frac{\varphi^{\prime}\left(d_{t}\right)}{\varphi^{\prime}\left(d_{t+1}\right)}$ differs from that of the household. The first derivative of the dividend adjustment costs (Eq. (4)) is a positive function of the level of dividend payouts. A oneoff decrease in dividend payments (where $\varphi^{\prime}\left(d_{t}\right)$ decreases but not $\varphi^{\prime}\left(d_{t+1}\right)$ ) lowers the discount factor applicable to firms. A more gradual decrease of dividend payments, on the other hand (where $\varphi^{\prime}\left(d_{t}\right)$ increases by less than $\varphi^{\prime}\left(d_{t+1}\right)$ ), raises the discount factor.

\subsection{Households}

The representative household maximises the expected utility function defined over

$E_{0} \sum_{t=0}^{\infty} \beta^{t} \frac{\left(c_{t}-\psi n_{t}^{\theta} x_{t}\right)^{1-\sigma}-1}{1-\sigma}$

where

$x_{t}=c_{t}^{\gamma} x_{t-1}^{1-\gamma}$

consumption, $c_{t}$, and labour effort, $n_{t}$. Following Jaimovich and Rebelo (2008), we choose a functional form for the utility function that allows utility to be both separable $(\gamma \approx 1)$ and non-separable $(\gamma \approx 0)$ over consumption and hours worked. The household's discount factor is denoted by $\beta$ and has the usual properties that $0<\beta<1$. Expected utility is maximised subject to the following budget constraint:

$w_{t} n_{t}+b_{t-1}+s_{t}\left(d_{t}+p_{t}\right)=\frac{b_{t}}{1+r_{t}}+s_{t+1} p_{t}+c_{t}+T_{t}$

At the beginning of each period, the household receives wage income, $w_{t} n_{t}$, and a dividend payment, $d_{t}$. The household also holds a stock of internationally traded bonds, $b_{t-1}$. The household's income steam is used to purchase consumption goods, pay taxes, $T_{t}$, and purchase new bonds, $b_{t}$ at a price of $1 /\left(1+r_{t}\right)$ per unit, and purchase new shares, $s_{t+1}$, at price $p_{t}$. Taxation, which the household takes as given, is used to finance the tax benefit enjoyed by firms when borrowing: $T_{t}=b_{t}^{f} / R_{t}-b_{t}^{f} /\left(1+r_{t}\right)$.

The representative household maximises expected utility, Eq. (10) subject to Eqs. (11) and (12). The household's first-order conditions for the optimal choice of $c_{t}, n_{t}, x_{t}, b_{t}$ and $s_{t+1}$ are:

$$
\begin{aligned}
& \left(c_{t}-\psi n_{t}^{\theta} x_{t}\right)^{-\sigma}+\omega_{t} \gamma c_{t}^{\gamma-1} x_{t-1}^{1-\gamma}=\lambda_{t} \\
& \left(c_{t}-\psi n_{t}^{\theta} x_{t}\right)^{-\sigma} \theta \psi n_{t}^{\theta-1} x_{t}=\lambda_{t} w_{t} \\
& \left(c_{t}-\psi n_{t}^{\theta} x_{t}\right)^{-\sigma} \psi n_{t}^{\theta}+\omega_{t}=\beta E_{t} \omega_{t+1}(1-\gamma) c_{t+1}^{\gamma} x_{t}^{-\gamma} \\
& \frac{\beta E_{t} \lambda_{t+1}}{\lambda_{t}}\left(1+r_{t}\right)=1 \\
& \frac{\beta E_{t} \lambda_{t+1}}{\lambda_{t}}\left(d_{t+1}+p_{t+1}\right)=p_{t}
\end{aligned}
$$

where $\omega_{t}$ and $\lambda_{t}$ are the Lagrange multipliers associated with constraints (11) and (12), respectively.

\subsection{Consolidated budget constraint}

Combining the budget constraints of the representative firm Eq. (5) with that of the representative household Eq. (12) and aggregating over all individuals yields the economy-wide budget constraint $^{7}$ :

$F\left(z_{t}, k_{t-1}, n_{t}\right)=c_{t}+i_{t}+\frac{\left(b_{t}-b_{t}^{f}\right)}{1+r_{t}}-\left(b_{t-1}-b_{t-1}^{f}\right)+\varphi\left(d_{t}\right)-d_{t}$

Where the net foreign asset position is defined as the difference between household savings and firm borrowing, $N F A_{t}=\left(b_{t}-b_{t}^{f}\right)$. It is the net foreign asset position that determines the size of the risk premium faced by households and firms when borrowing in world markets. The interest rate payable on bonds, $r_{t}$ is equal to the world interest rate, $r_{t}^{*}$ adjusted for a debt elastic risk-premium. The spread (or discount) relative to the world interest rate depends on the debt position of the economy:

$\left(1+r_{t}\right)=\left(1+r_{t}^{*}\right) e^{-\zeta\left(\frac{N F A_{t}}{y_{t}}-N \bar{F} A\right)}$

The appendix shows that our results are not sensitive to either the assumed value of $\zeta$, nor to the specific way that we have 'closed' the model. The trade balance, which we assume to be zero in the steady state, is defined as:

$T B_{t}=y_{t}-c_{t}-i_{t}-\varphi\left(d_{t}\right)+d_{t}$

7 The number of shares held by all households is normalised to unity. 

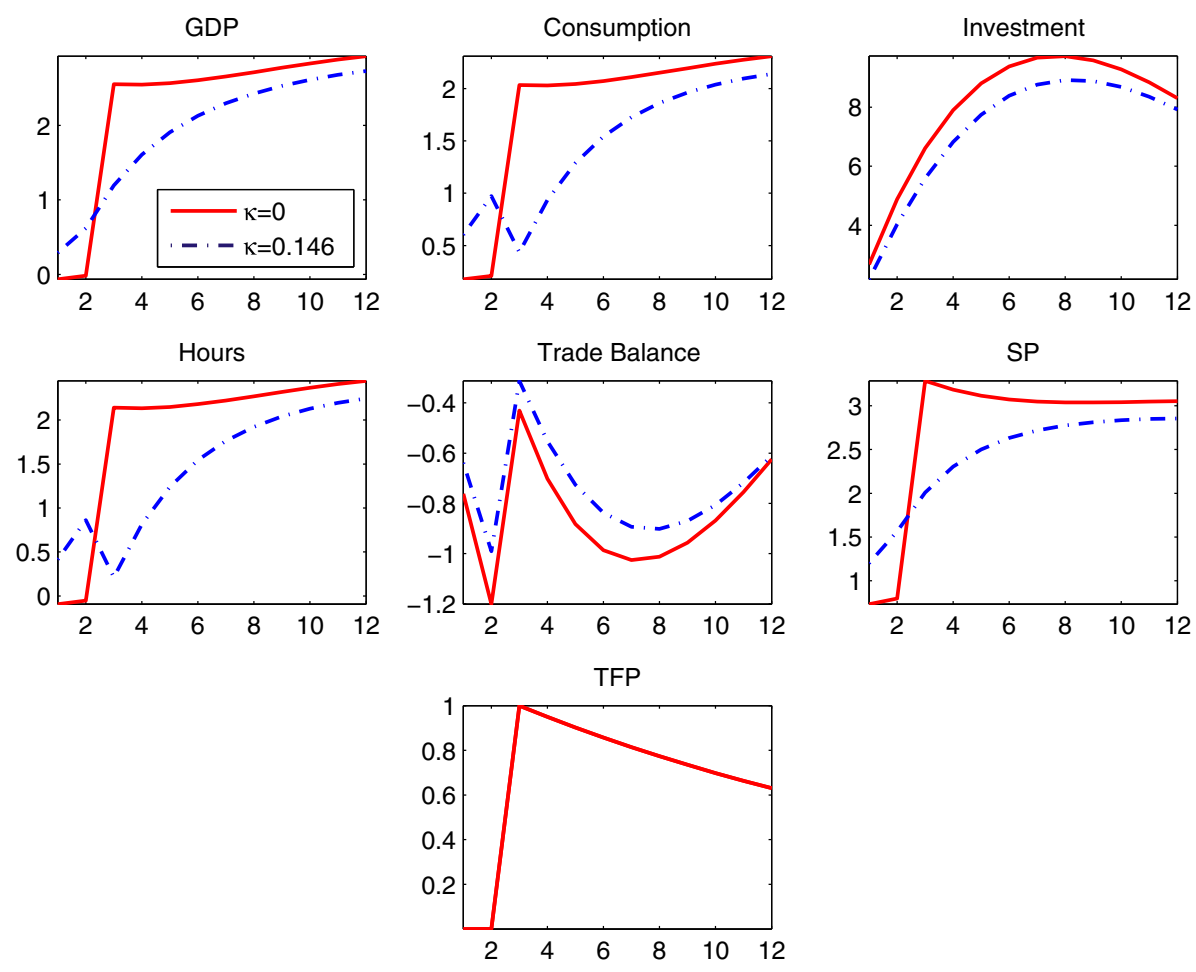

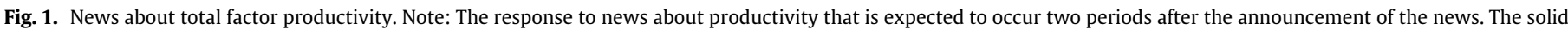

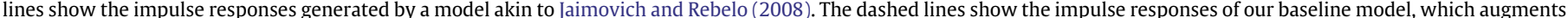

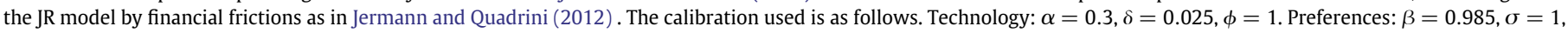
$\theta=1.2, \gamma=0.001, \bar{n}=0.2$. Financial frictions: $\xi=0.162, \tau=0.35, \kappa=$ varied, Bond holding cost: 0.001 .

\section{News about total factor productivity}

In Figs. 1 to 2 we assess the contribution of financial frictions to the generation of positive co-movement between consumption and hours worked in response to news shocks. To do this, we compare our baseline model to a version where the dividend payout cost is set to zero. This version of our model is similar to the model in Jaimovich and Rebelo (2008). The calibration of our model follows Jermann and Quadrini (2012) for the financial frictions part of the model, such that $\xi=0.162$ and $\tau=0.35$. We set $\kappa=0.146$, which corresponds to the value in Jermann and Quadrini (2012). Sensitivity analysis shows that in our baseline calibration with non-separable preferences, we get news-driven business cycles for any positive value of $\kappa$. For separable preferences (when $\gamma=0.999$ ), our model generates news-driven business cycles for any value of $\kappa$ greater than 0.09 .

For technology, we use standard parameters from the literature. The share of capital in output, the depreciation rate as well as the investment adjustment cost parameter are $\alpha=0.3, \delta=0.025, \phi=$ 1 , respectively. In terms of preferences, we assume a value for the risk free discount rate of $\beta=0.985$. The parameters of the utility function are $\sigma=1, \theta=1.2$ and $\gamma=0.001$. The value of $\psi$ is set in such a way as to yield a steady state value of hours worked of $\bar{n}=0.2$. The elasticity of the interest rate to changes in net foreign asset position, is set at $\zeta=0.001$.

Fig. 1 analyses the response of key macroeconomic aggregates to an increase in TFP that is expected to occur in period $t+2$ and announced in period $t .{ }^{8}$ In our baseline model, hours worked and GDP both increase as soon as the news about future productivity

\footnotetext{
8 We follow business cycle tradition in analysing the responses of temporary rather than permanent shocks. In the news literature, there are examples of both.
}

becomes available. Without financial frictions, the agent's preferences over consumption and labour ensure that the wealth effect on hours worked is weak. However, given our value of $\gamma$, the wealth effect is small, but not zero, and hence hours worked decline on impact. Because the real interest rate stays largely constant in our small open economy model, share prices rise with the announcement of news. The initial increase in consumption and investment is greater than the response of output, leading to a deterioration of the trade balance and a decline in the economy's net foreign asset position. Because of the way we have closed the model using a small debt-elastic interest rate risk premium, $\zeta$ in Eq. (19), the decline in the net foreign asset position raises the real interest rate faced by households and firms and thus also affects the path of consumption and investment.

In the baseline model, labour effort rises on impact because an anticipated shock to TFP drives a wedge between the marginal product of labour and the real wage. This wedge can be easily illustrated by combining the household's and the firm's first-order conditions for labour. For expositional purposes, we assume that $\gamma=0$, such that the wealth effect on hours is absent.

$F_{n}\left(z_{t}, k_{t-1}, n_{t}\right)\left(1-\Delta_{t} \varphi^{\prime}\left(d_{t}\right)\right)=\theta \psi n_{t}^{\theta-1}$

Following a positive news shock about TFP the term $\Delta_{t} \varphi^{\prime}\left(d_{t}\right)$ falls, which for a given marginal product of labour raises the real wage. The rise in the real wage causes agents to increase hours worked and thus output to rise.

Once TFP increases, the firm's borrowing constraint becomes more binding, $\Delta_{t}$ rises, due to more output needing to be financed in advance of production. A feature of the Jermann and Quadrini (2012) model is that a tightening of the borrowing constraint causes hours 

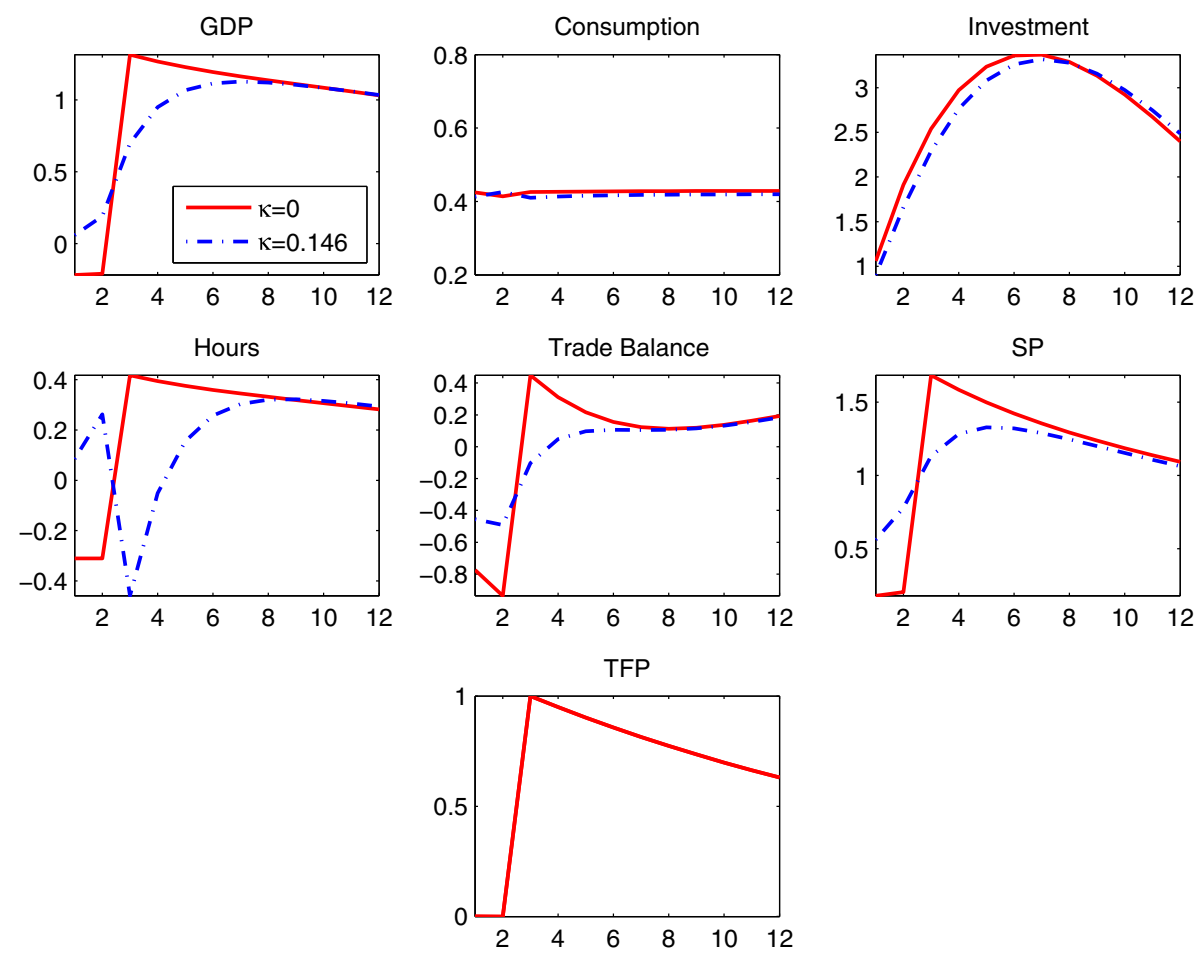

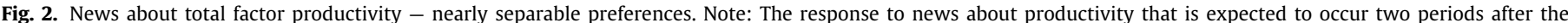

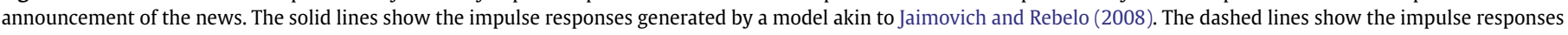

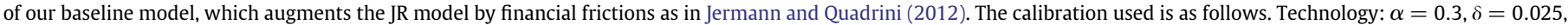
$\phi=1$. Preferences: $\beta=0.985, \sigma=1, \theta=1.2, \gamma=0.99, \bar{n}=0.2$. Financial frictions: $\xi=0.162, \tau=0.35$, $\kappa=$ varied, Bond holding cost: 0.001 .

worked to decline. In the next subsection, we analyse why the borrowing constraint is relaxed during the news period, causing hours worked to rise.

\subsection{Intuition}

In Jermann and Quadrini (2012) a positive contemporaneous TFP shock causes firms to reduce their dividend payouts, $d_{t}$. The reason for the fall in dividends is as follows: A positive TFP shock raises the marginal products of both capital and labour, causing the firm to expand labour input and capital accumulation. Because of the aforementioned mismatch in the timing of revenues and expenditure, the representative firm in this model requires a working capital loan. Limited enforcement ensures that the size of the working capital loan, $l_{t}$, is constrained by the net worth of the firm:

$$
\xi\left(k_{t}-\frac{b_{t}^{f}}{1+r_{t}}\right)=l_{t}=w_{t} n_{t}+i_{t}+d_{t}+b_{t-1}^{f}-\frac{b_{t}^{f}}{R_{t}} .
$$

In order to raise the funds to increase $w_{t} n_{t}+i_{t}$ in response to a TFP shock the firm has to cut dividend payouts, $d_{t}$.

Without dividend adjustment costs, i.e. $\varphi^{\prime}=1$, dividends can be reduced sufficiently for labour demand and investment to rise, just as in the standard RBC model. In the presence of dividend adjustment costs, the decline in dividend payouts is less pronounced. Importantly, the dynamics of dividends now affect the firm's stochastic discount factor.

$\beta \frac{\lambda_{t+1}}{\lambda_{t}} \frac{\varphi^{\prime}\left(d_{t}\right)}{\varphi^{\prime}\left(d_{t+1}\right)}$

As dividend payouts decline on impact and then recover, the discount factor falls. In other words, the firm becomes less patient and thus faces a more binding borrowing constraint. As a result, the firm's demand for labour declines. This mechanism explains the observed decline in hours worked once the anticipated increase in TFP materialises in Figs. 1 to 2.

When the increase in TFP is anticipated, the firm finds it optimal to start reducing the flow of dividends before TFP actually increases in order to finance increased investment. Thus dividends start to decline as soon as the news about future TFP becomes available. As in the case of an unanticipated increase in TFP, dividend adjustment costs reduce the magnitude of the fall in dividend payouts and smooth the dynamics of $d_{t}$. The gradual fall in dividends affects the firm's stochastic discount factor via the dividend adjustment cost function. When dividends are expected to fall over time, the firm's discount factor rises, which makes the firm want to hold less debt. Therefore, the firm's desire to gradually reduce dividend payments in order to expand investment and labour input also leads to a de-leveraging of the firm.

The combination of a higher expected capital stock and lower inter temporal borrowing thus improves the firm's net asset position, which in turn relaxes the intra-temporal borrowing constraint. The less binding the constraint, the smaller $\Delta_{t}$ and the greater will be the firm's demand for labour (see Eq. (6)). This mechanism explains the role of financial frictions in generating news-driven business cycles in our model. Importantly, as we show in Fig. 2, this mechanism can be strong enough to off-set the wealth effect on hours worked.

\subsection{Separable preferences}

In this section, we examine whether the mechanism identified above is strong enough to overcome the negative wealth effect on hours that one finds in models with separable preferences over consumption and labour. The utility function put forward by Jaimovich and Rebelo (2008) nests both non-separable (when $\gamma$ is close to zero) 
and separable preferences (when $\gamma$ is close to unity) over consumption and labour. Fig. 2 shows the response to a news shock when $\gamma=0.99$ for an otherwise unchanged calibration. Even with largely separable preferences, GDP and its components display typical business cycle behaviour, with output, consumption and investment and hours all rising on impact. As in the non-separable case, there is a reduction in labour demand once TFP actually increases. This is because as output rises, so does the demand for intra-period finance, which in turn causes the enforcement constraint to tighten.

\section{Data}

Next, we estimate a VAR model using data on total factor productivity, stock prices and five macroeconomic aggregates: output, consumption, investment, total hours worked and net trade. Where applicable, our data is normalised by the relevant working age population. For each country our data is from OECD and obtained via HAVER. Our sample period is mainly dictated by data availability and covers 1989 Q3 to 2011 Q3.

Our macroeconomic aggregates and our measure of stock prices are constructed as follows: Output: $\log$ (GDP in millions of chain linked domestic currency/working age population); Consumption: $\log$ (Private consumption in millions of chain linked domestic currency/working age population); Investment: log(Private non-residential fixed capital formation in millions of chain linked domestic currency / working age population); Total hours: $\log ($ Employment in thousands $\times$ Hours worked per employee in total economy / working age population); Net trade to GDP: (Export of goods and services in millions of chain linked domestic currency/GDP in millions of chain linked domestic currency - Imports of goods and services in millions of chain linked domestic currency/GDP in millions of chain linked domestic currency); Stock prices: $\log$ (Stock prices / Consumer price index). We use the following stock price series: 'All Ordinaries' for Australia, S\&P/TSX Composite index for Canada, NZSX Mid Cap for New Zealand and the FTSE 100 for the UK.

\subsection{A measure of total factor productivity}

Our method of constructing quarterly total factor productivity is based on Fernald (2014). Basu et al. (2006) argue that because of sectoral heterogeneity in the marginal product of factors, one should ideally measure TFP at the sectoral level and then aggregate across sectors to derive an aggregate measure of TFP. Furthermore, unobserved variations in factor utilisation must also be accounted for. They proxy the unobserved changes in capital utilisation and labour effort by observed changes in hours worked per capita.

Fernald (2014) derives a quarterly measure of TFP that does not require annual sectoral data, but does rely on the annual estimates for utilisation from Basu et al. (2006). Unfortunately, there are no corresponding studies for the small open economies in our sample. Instead, we construct our own series of TFP using readily available quarterly data. As in Basu et al. (2006) and Fernald (2014), we use a growth-accounting approach. Assume that quarterly per capita output growth is modelled by Cobb-Douglas production function:

$d y_{t}=d a_{t}+\alpha\left(d u_{t}+d k_{t}\right)+(1-\alpha)\left(d e_{t}+d n_{t}\right)$

where $y_{t}$ is output $a_{t}$ is total factor productivity, $u_{t}$ is capital utilisation rate, $k_{t}$ is physical capital input, $n_{t}$ is total hours worked, $e_{t}$ is effort and $\alpha$ is the capital share.

Whereas data on capital utilisation, hours worked, output and total labour force are available for our sample of countries at quarterly frequency, we have to construct quarterly data for effort and the capital stock. We follow Basu et al. (2006) and proxy the change in effort by the change in average hours, $d e_{t}=\zeta d n_{t}$. To construct a quarterly series of the capital stock, we use annual capital data from the OECD and transform it to quarterly frequency using information on quarterly investment. Our approach consists of allocating capital into each quarter proportionally to the investment on that particular quarter.

Consistently with the calibration of our model we set $\alpha$ to 0.3 . The coefficient that links changes in effort to hours worked, $\zeta$ is set to 1 . We have experimented with values between 0.1 and 10 and found that our results are robust provided $\zeta$ is non-zero.

Output, $y_{t}$ and total hours $n_{t}$ are defined as above. We construct a quarterly measure of the capital stock using annual OECD data on 'Productive capital stock', and quarterly investment. As defined above, investment is taken from the OECD's private non-residential fixed capital formation series. For each quarter, we use the share of total investment over the whole year occurring in this quarter in order to determine this quarter's change in the total capital stock from this year to the next. Therefore, our constructed quarterly capital stock is consistent with annual capital stock taken from the data.

HAVER supplies measures of capacity utilisation from a number of sources. For Australia, we use the NAB Business Survey's measure of capacity utilisation, for Canada, we use the 'Capacity Utilisation total industry' measure. For the UK, we use the Harmonized Capacity Utilisation series and for New Zealand, we use capacity utilisation in manufacturing and construction. All series are reported in percentages and divided by 100 .

\subsection{Country-specific shocks}

It is likely that TFP growth in small open economies has both a domestic as well as a foreign component. To take account of this, we would ideally adjust our TFP series by a measure of global TFP to allow us to isolate country-specific shocks to TFP. There is, however, no obvious measure of world TFP available, hence we take the quarterly TFP series by Fernald (2014), for the United States as a proxy.

\subsection{Stock prices and macroeconomic aggregates}

Stock prices are stock market indexes deflated by CPI for each country. Output and consumption correspond to gross domestic product and private consumption in real prices, respectively. Investment refers to private non-residential fixed capital formation in real prices. Total hours for each country is constructed as a product of employment and hours worked per employee. All macroeconomic aggregates are divided by the working age population and are therefore expressed in per capita terms. Net trade is the the difference between exports and imports of goods and services divided by output.

\section{The time series model}

In this section we describe the structure of the time-series model and explains its estimation details. Our empirical model is a vector autoregressive model of order $K-\operatorname{VAR}(K)$

$\tilde{y}_{t}=\sum_{i=1}^{K} \Theta_{i} \tilde{y}_{t-i}+u_{t}$

where $u_{t}$ is the $N \times 1$ vector of reduced-form errors that is normally distributed with zero and $\Sigma$ variance-covariance matrix. It is helpful to re-express the VAR model in the following format

$Y=X \Psi+V$ 
where $Y=\left[\tilde{y}_{h+1}, \ldots, \tilde{y}_{T}\right]$ is a $N \times T$ matrix containing all the data points in $\tilde{y}_{t}, X=Y_{-h}$ is a $(N K) \times T$ matrix containing the $h$-th lag of $Y$, $\Theta=\left[\Theta_{1} \cdots \Theta_{K}\right]$ is a $N \times(N K)$ matrix, and $U=\left[u_{h+1}, \ldots, u_{T}\right]$ is a $N \times T$ matrix of disturbances.

The number of lags has been selected using information criteria (likelihood ratio test statistic, final prediction error and Akaike's information criterion). All selection criteria suggest that a VAR model with two lags is sufficient to capture the dynamic properties of the macroeconomic data and this is the case for all countries. In order to ensure that our inference is not driven by the selection of a particular lag length we repeat the same analysis using lag choices (VAR(1), $\operatorname{VAR}(3)$ and $\operatorname{VAR}(4))$ and the results remain unchanged.

For the estimation of the empirical model we rely on Bayesian inference techniques as the large dimension of the observable vector (seven variables) and the small time span of the macroeconomic data set cause Classical (OLS) estimates to be subject of considerable uncertainty. In this case data is combined with prior information about the reduced-form parameter vector in the form of a probability density function. Similar to Beaudry et al. (2011b) we employ a flat Normal-Wishart conjugate prior that leads (after being combined with the likelihood of the model) to a closed-form posterior probability distribution for the VAR parameter vector ${ }^{9}$.

\subsection{Identification}

As in Beaudry et al. (2011b), we identify news TFP shock using a combination of zero type and sign restrictions (Uhlig (2005)). To be precise, the TFP shock anticipated in $t+h$ period is identified by imposing zero restrictions on TFP for periods $t, t+1, \ldots, t+h-1$ and sign restrictions on the responses of a set of variables in the system.

Our theoretical model suggests that news shocks are associated with positive co-movement between macroeconomic aggregates and share prices as well as a counter-cyclical current account. Based on this analysis, we impose that stock prices and consumption increase after a positive news about future TFP.

Our methodological strategy also enables us to consider, in a VAR framework, news shocks beyond the first period (see, Barsky and Sims, 2011 and Beaudry et al., 2011b). That makes the VAR identified responses more comparable to DSGE ones so the former responses can serve a useful device to either assess the empirical predictions of the structural model about new shocks and/or to calibrate the structural parameter vector in order for the DSGE model to replicate the responses estimated in the data. This closes an important gap in the literature since so far the comparison was achievable only for DSGE model with only one quarter anticipation period (see Barsky and Sims, 2011, Kurmann and Otrok, 2013, Theodoridis and Zanetti, 2013 and Pinter et al., 2013).

In order to make the paper self contained we describe in this section the mechanics of the identification process starting from the vector moving average representation of the system (Eq. (23)). Under relatively weak restrictions (see Lutkepohl, 2007) the reduced-from model (23) has the following moving average representation

$\tilde{y}_{t}=B(L) v_{t}$

The mapping between the reduced-form errors and the structural shocks is given by

$v_{t}=A \varepsilon_{t}$

with $A A^{\prime}=\Sigma$. For any arbitrary orthogonalization of $\Sigma$ such as the Cholesky decomposition $\Sigma=\tilde{A} \tilde{A}^{\prime}$ and an orthonormal matrix such

\footnotetext{
9 See Kadiyala and Karlsson (1997) for a detailed discussion.
}

that $D D^{\prime}=I_{d y}$ (where $I_{d y}$ is the $d y \times d y$ identity matrix) the mapping between the reduced-form and structural errors can be re-expressed as

$v_{t}=\tilde{\mathrm{A}} D \varepsilon_{t}$

Having identified the structural shocks, the response of variable $j$ to shock $i$ in period $h$ can be obtained as

$R(j, i, h)=J_{j} \breve{\Theta}^{h-1}\left(\mathbf{1}_{K} \otimes \tilde{\mathrm{A}} D\right) J_{i}^{\prime}$

where $\breve{\Theta}$ is the companion matrix of the system (Eq. 23), $\mathbf{1}_{K}$ is a $(K \times 1)$ vector of ones, $\otimes$ denotes the Kronecker product and $J_{v}$ is a selection $(1 \times K d y)$ vector of one in position $v$ and zeros everywhere else.

As discussed earlier, the identification of the news shock requires - in addition to some zero type restrictions - the response of a set of variables indexed by $\mathcal{R}_{+}$to be positive and these restrictions can last for a number of periods $\mathcal{H}_{+}$. Beaudry et al. (2011b) achieve the identification of the news shock by employing the procedure developed by Uhlig (2005) and Mountford and Uhlig (2009), known as a penalty function approach. This framework allows the user to easily combine zero and sign restrictions by solving the following minimisation problem

$$
d^{*}=\arg \min \sum_{j \in \mathcal{R}_{+}} \sum_{h_{j}=\tilde{h}_{j}}^{\mathcal{H}_{j,+} \in \mathcal{H}_{+}} f\left(-\frac{J_{j} \breve{\Theta}^{h-1}\left(\mathbf{1}_{K} \otimes \tilde{\mathrm{A}} d\right)}{\sigma_{j}}\right)
$$

s.t.

$d^{\prime} d=1$

$R(1,2, \tilde{h})=0$

where $d=D e_{i}^{\prime}, \tilde{h}=1,2,3, e_{i}$ denotes the column $i$ of $I_{N}, \sigma_{j}$ is the standard deviation of $R(j, i, h)$ and $f(x)=\left\{\begin{array}{l}100 x \text { if } x \geq 0 \\ x \text { otherwise }\end{array}\right.$. Expression (29) indicates that $d^{*}$ must be a column of an orthonormal matrix $D$, while Eq. (30) says that the news shock $(i=2)$ cannot have an effect on TFP $(j=1)$ for periods $\tilde{h}$. Finally, the objective function (28) is scaled by the standard deviation of impulse response $R(j, i, h)$ to make it comparable across different variables.

In summary, the identification puts restrictions on the responses of TFP, consumption and share prices. TFP is restricted to remain at zero for two quarters and positive for the following two quarters. Consumption and share prices are restricted to increase for four quarters following a positive news shock.

\subsection{Testing the identification technique on simulated model data}

In this section, we perform a Monte-Carlo experiment to compare the true impulse responses to news shocks from the model presented in the previous section and those from a VAR using our identification scheme.

In order to estimate a VAR with as many variables as we have in the empirical section, we introduce additional structural shocks into our model. In addition to news about TFP, we also consider a standard contemporary TFP shock plus five additional shocks. These are shocks to investment specific technology, financial shocks as in Jermann and Quadrini (2012), government spending shocks and preference shocks and a shock to the world real interest rate. The standard deviation 
of the two unanticipated technology shocks (TFP and investment specific) is set to $0.75 \%$, the standard deviation of the news shock is set to $0.25 \%$ and the standard deviation of all other shocks is set to $0.15 \%$. All shocks are assumed to have an AR(1) coefficient of 0.95 .

We generate 2000 artificial data sets from the model under our calibration corresponding to Fig. 1. The sample size of each data set is 86 , corresponding to the number of observations of the actual data. Using the artificial data sets, we estimate VARs with TFP, output, consumption, investment, total hours worked, net trade and stock prices as observables. The VARs include two lags. We then identify impulse responses using the same identification restriction employed in the empirical section.

Fig. 3 displays the theoretical and the range of estimated impulses responses over the Monte-Carlo repetitions. Model based impulse responses are dashed blue and the shaded area represents \pm one standard deviation confidence intervals for the estimated impulse responses. The VAR based impulse responses are able to capture the model based dynamics following a news shock. Output and its components, total hours as well as share prices, are all estimated to respond positively while the VAR correctly identifies the negative response of net trade. The VARs somewhat underestimate the magnitude of macroeconomic effects of a news shock, particularly at longer horizons. This bias is probably related to the truncation of the empirical model, as we only use two lags. When we expand the lag order to 4 , this bias almost disappears. Nevertheless, the theoretical impulse responses almost always lie within the range of estimated impulse responses. These result suggest that our identification successfully recovers news shocks.

As in Barsky and Sims (2011), we argue that our Monte Carlo results suggest that the invertibility or 'fundamentalness' issue raised by Fernndez-Villaverde et al. (2007) is not a major cause for concern for our work.

\section{Empirical results}

In this section, we discuss impulse responses and forecast error variance decompositions obtained from the structural VAR. Fig. 4 shows the estimated impulse responses in four countries for TFP, output, consumption, total hours, investment, net trade and stock prices. The grey shaded area represents 16 th and 84th quantiles. As per our identification restrictions, TFP remains constant for two periods and increases after the zero restrictions end, and consumption and stock prices increase on impact. After the identification restriction, the impact of the news shock is significantly positive for all these three variables. The quantitative impact of the news shock is similar for TFP and consumption in all countries. Possibly reflecting their volatility, the impact response of stock prices are one order of magnitude higher than the response of TFP.

Now consider the response of other variables which are not subject to any identification restrictions. A first robust finding is that in all countries, output is estimated to increase in response to news. Except for New Zealand, output rises on impact. This is, for example, contrary to Barsky and Sims (2011) who find that, in the US, the output response to a news about future TFP tracks, but does not anticipate the movements in the estimated path of TFP. In our sample of small open economies, positive news about future TFP creates an economic boom on impact and its positive effects on output are estimated to be persistent. Second, total hours and investment are also estimated to persistently increase after a news shock. There is, however, somewhat more heterogeneity in the response of these two variables. In the case of the United Kingdom, in particular, the response of these two variables seem to be building up over time and less front loaded than in the other countries. The impulse responses described so far imply that, for the small open economies we consider, news shock generate a positive co-movement between
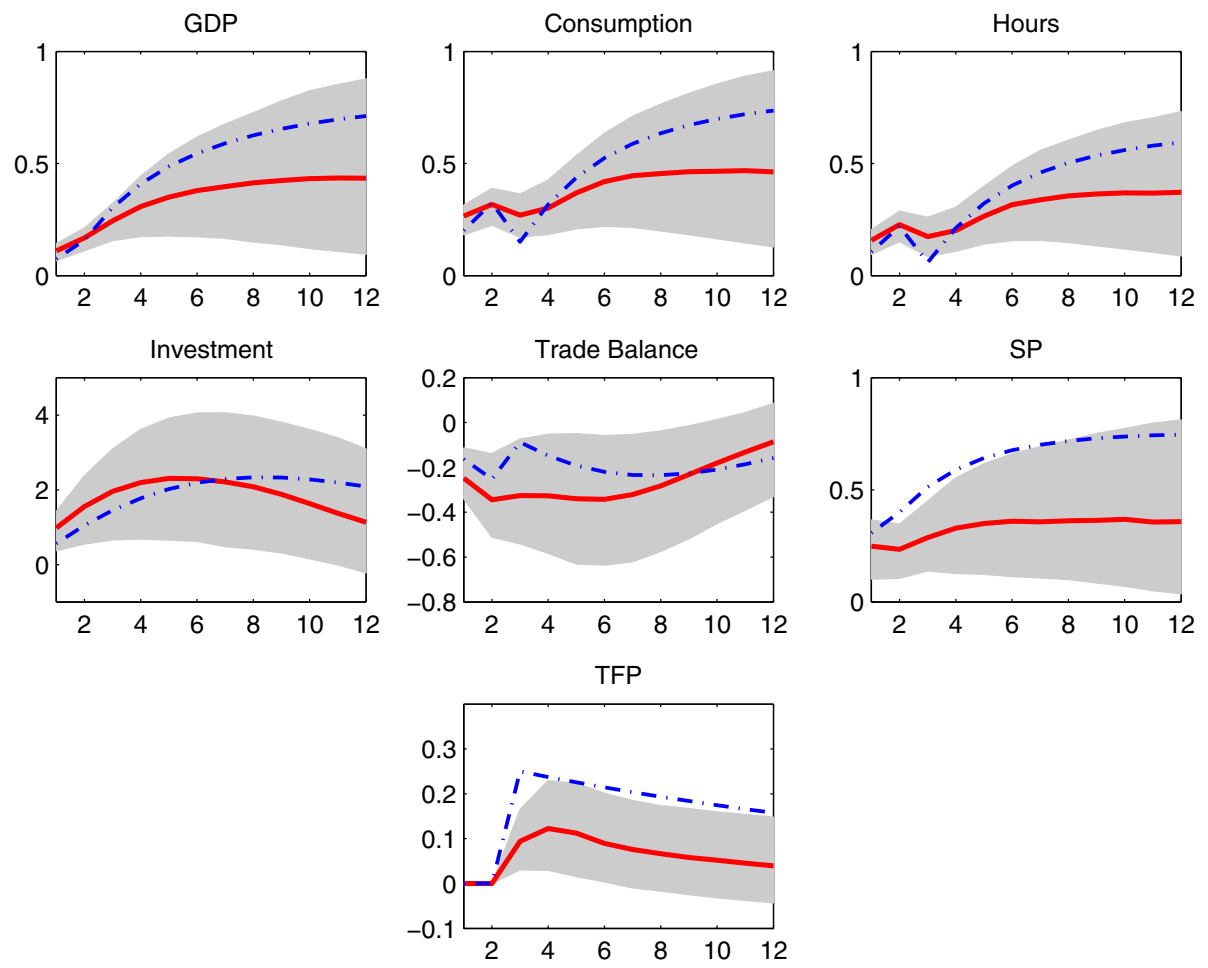

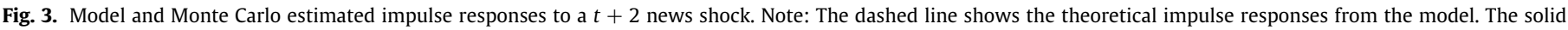

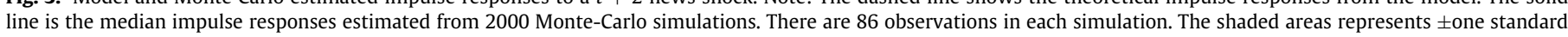
deviation confidence bands from the 2000 Monte-Carlo simulations. 

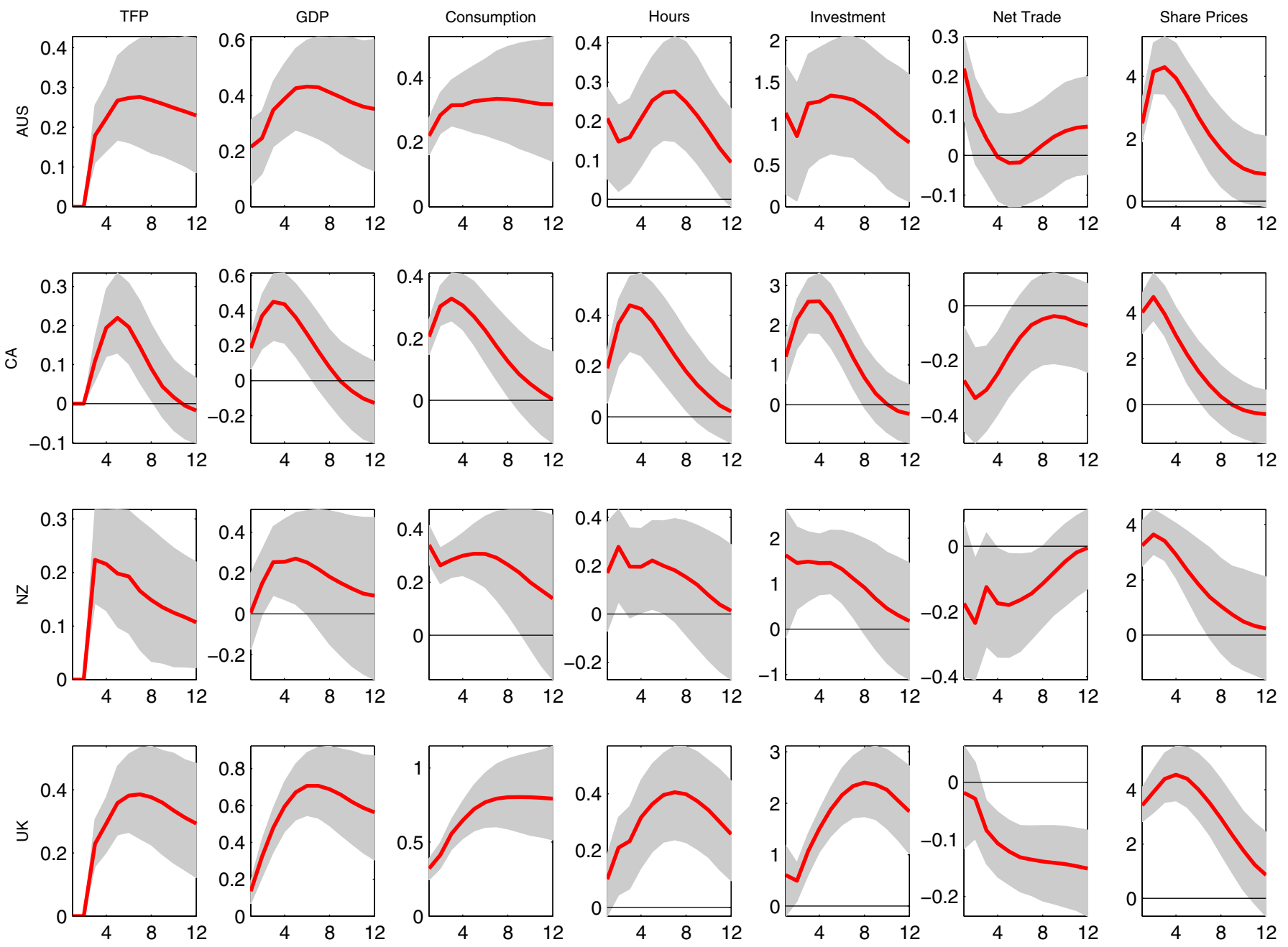

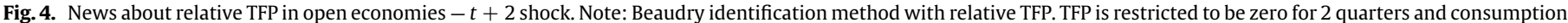
and stock prices are restricted to increase on impact.

output, consumption, investment and total hours. Third, net trade is countercyclical in all countries except Australia following a positive news shock, with some differences in the initial responses. Except for Canada, the initial response of net trade is small and is followed with further deteriorations.

Comparing Figs. 1 and 4 shows that the estimated impulse responses are qualitatively similar to those of our model. In both cases, there is co-movement between GDP, consumption, investment and hours as well as a counter-cyclical trade balance. Model and data do, however, differ with respect to the persistence of GDP, consumption and hours as well as with respect to the magnitude of the response of share prices. Compared to the data, the model predicts a more persistent response for GDP, consumption and hours and a less volatile one for share prices.

We now turn to the relative importance of the identified news shocks in shaping the business cycle dynamics in our set of small open economies. Table 1 reports the share of the news shock in the forecast error variance decomposition for the seven variables in the VAR. The news shock accounts for between $6 \%$ to $40 \%$ of the 10 quarter ahead forecast error variance of GDP. For consumption, the figures are between $13 \%$ and $42 \%$, and for investment between $11 \%$ and $44 \%$. The shock also accounts for between $7 \%$ and $20 \%$ of the 10 -quarter ahead forecast error variance of net trade.
The large range of these results reflects heterogeneity between countries. In the United Kingdom, the contribution of new shocks to the 10-quarter ahead forecast error variance of GDP is much greater than in Australia, Canada or New Zealand. In New Zealand, news shocks appear to play only a minor role. Whereas in the UK, they account for around $40 \%$ of the 10 -quarter ahead forecast error variance of GDP, in New Zealand these shocks only contribute around $6 \%$. The role of news shocks in Australian and Canadian GDP is more important than in New Zealand, but in both of these countries the forecast error variance is still only about a two-thirds to half of that of the UK. That country-specific news shocks are somewhat less important in the smaller and more open economies in our sample is in line with the well documented importance of foreign shocks for these economies, see for instance Justiniano and Preston (2010).

\subsection{News shocks and relative prices}

The choice of variables in our baseline VAR is determined by our theoretical model. As such, we abstract from relative price movements and focus on net trade. In Fig. 5, we examine a VAR augmented by two measures of relative prices, country $i$ 's real exchange rate vis-a-vis the United States and the terms of trade measured as the relative price of exports to imports. In both measures, an increase 


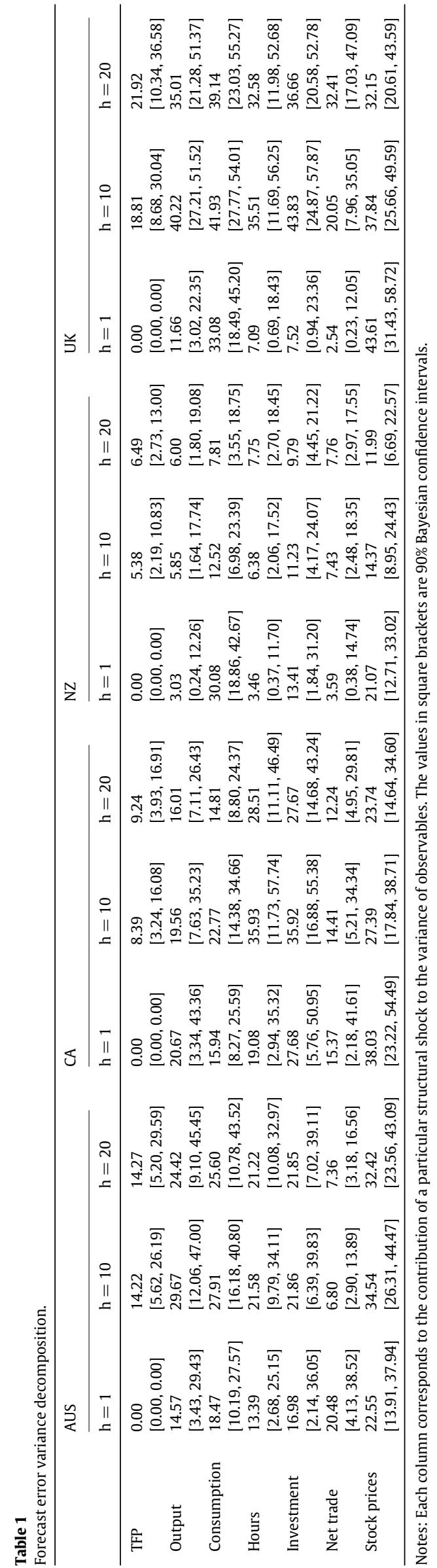

denotes an appreciation. We also replace net trade by real exports and real imports.

In the VAR, the response of the real exchange rate is not restricted, while the identification scheme is the same as our baseline formulation. For all countries, the median response the real exchange rate to news shock is an initial real appreciation. This appreciation is, however, relatively short lived and not statistically significant for New Zealand. As the news about TFP is realised and TFP increases, the real exchange rate depreciates as the increased supply of home produced goods depresses its relative price. The qualitative dynamics of the other variables in our VAR remain unchanged.

For Canada and the UK, we also observe a significant appreciation of the terms of trade. For our two antipodean commodity exporters, the initial response of the terms of trade is not statistically significant. This suggests that for these small open economies, the terms of trade is exogenous. For Canada and the UK, the real appreciation of the terms of trade suggests that the observed real exchange rate appreciation is not attributable to an increase in the relative price of non-traded goods.

\subsection{News shocks and behaviour of imports and exports}

So far, our analysis suggests that, except for Australia, news shocks cause a worsening of the net trade position. This is in line with our theoretical model. In a small open economy, the demand for exported goods depends on its relative price and foreign aggregate demand. In Fig. 5, we follow Corsetti et al. (2014) and analyse real exports and real imports separately. For all countries in our sample, a positive news shock is associated with an increase in both real imports and real exports. Except for Australia, the response of imports is greater than the response of exports.

Figs. 4 and 5 suggest that a consistent picture emerges regarding macroeconomic dynamics conditional on news shocks in small open economies. Our results indicate that positive news shocks about future TFP are associated with initial increases in output, consumption, investment, total hours, stock prices and are associated with countercyclical net trade dynamics. These results appear to be in contrast with the recent empirical work focusing on the effect of TFP news shock on the US economy.

\section{Conclusion}

News about future TFP can be a source of business cycle fluctuations in small open economies. For a set of advanced small open economies, we show that news about future TFP causes positive comovement between GDP, hours, consumption and investment. News shocks are also associated with counter-cyclical current accounts. This is in contrast with previous studies focusing on the US economy in which news about future productivity are not associated with economic booms. We also find that the contribution of country specific news shock in the forecast error variance decomposition of macroeconomic variables is relatively modest. This is possibly due to larger share of foreign variables in driving business cycle dynamics in these small open economies.

In addition to our empirical contribution, we also put forward a theoretical small open economy model that is able to generate business cycles from news shocks to TFP. We introduce financial frictions, akin to those in Jermann and Quadrini (2012) as a mechanism to generate the positive co-movement between hours worked and consumption that is a challenge for canonical small open economy models. Our modelling approach is deliberately parsimonious in order to put forward a particular channel in generating news-driven business cycles. 

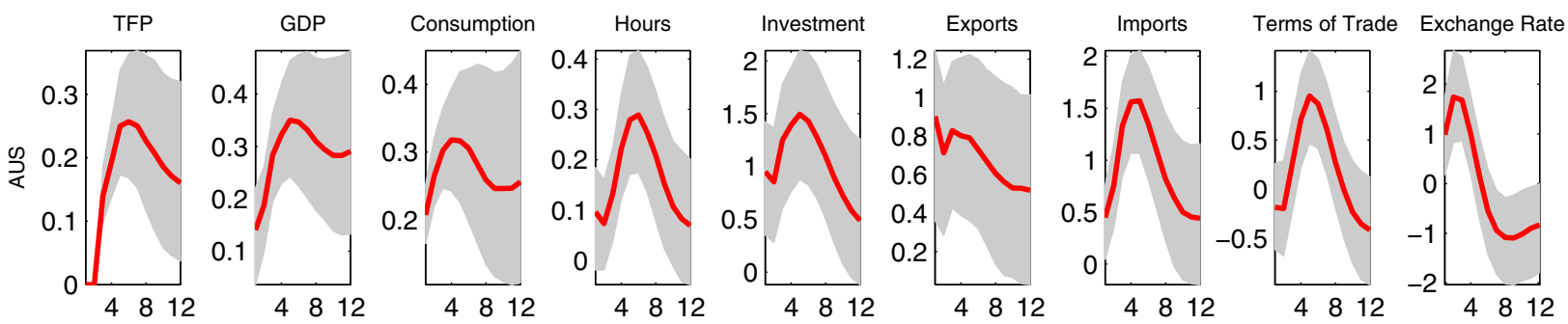

Share Prices
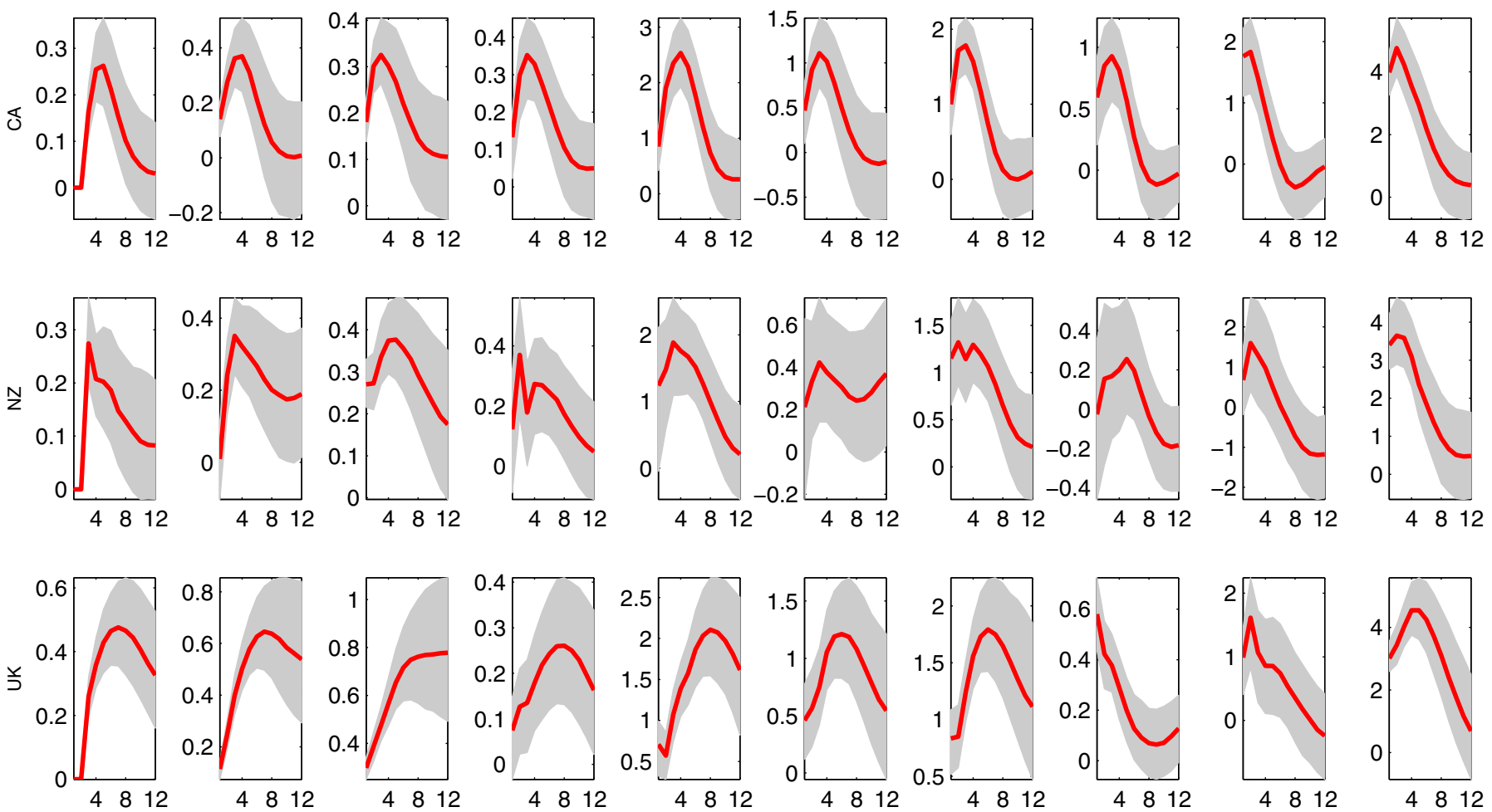

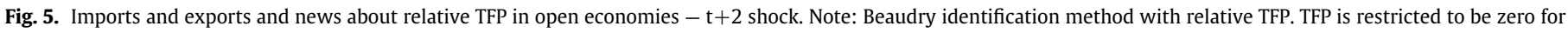
2 quarters and consumption and stock prices are restricted to increase on impact. VAR includes real imports and real exports.

\section{Appendix A. Supplementary data}

Supplementary data to this article can be found online at http:// dx.doi.org10.1016/j.jinteco.2016.12.005.

\section{References}

Aguiar, M., Gopinath, G., 2007. Emerging market business cycles: the cycle is the trend. J. Polit. Econ. 115 (1), 69-102.

Barsky, R.B., Sims, E.R., 2011. News shocks and business cycles. J. Monet. Econ. 58 (3), 273-289.

Basu, S., Fernald, J.G., Kimball, M.S., 2006, December. Are technology improvements contractionary? Am. Econ. Rev. 96 (5), 1418-1448.

Beaudry, P., Dupaigne, M., Portier, F., 2011, January. Modeling news-driven international business cycles. Rev. Econ. Dyn. 14 (1), 72-91.

Beaudry, P., Nam, D., Wang, J., 2011, Dec. Do mood swings drive business cycles and is it rational? NBER Working Papers 17651.National Bureau of Economic Research, Inc.

Beaudry, P., Portier, F., 2004, September. An exploration into Pigou's theory of cycles. J. Monet. Econ. 51 (6), 1183-1216.

Beaudry, P., Portier, F., 2006, September. Stock prices, news, and economic fluctuations. Am. Econ. Rev. 96 (4), 1293-1307.

Beaudry, P., Portier, F., 2007, July. When can changes in expectations cause business cycle fluctuations in neo-classical settings? J. Econ. Theory 135 (1), 458-477.

Christiano, L.J., Eichenbaum, M., Evans, C.L., 2005. Nominal rigidities and the dynamic effects of a shock to monetary policy. J. Polit. Econ. 113 (1), 1-45.

Corsetti, G., Dedola, L., Leduc, S., 2008a. International risk sharing and the transmission of productivity shocks. Rev. Econ. Stud. 75, 443-473.
Corsetti, G., Dedola, L., Leduc, S., 2008b. Productivity, external balance, and exchange rates: evidence on the transmission mechanism among G7 countries. NBER Int Semin. Macroecon. 117-178.

Corsetti, G., Dedola, L., Leduc, S., 2014. The international dimension of productivity and demand shocks in the US economy. J. Eur. Econ. Assoc. 12, 153-176.

Den Haan, W.J., Kaltenbrunner, G., 2009, April. Anticipated growth and business cycles in matching models. J. Monet. Econ. 56 (3), 309-327.

Den Haan, W.J., Lozej, M., 2010, July. Pigou cycles in closed and open economies with matching frictions. In: NBER International Seminar on Macroeconomics 2010. National Bureau of Economic Research, Inc., pp. 193-233.

Fernald, J.G., 2014. A quarterly, utilisation-adjusted series on total factor productivity. Federal Reserve Bank of San Francisco Working Paper (2012-19).

Fernndez-Villaverde, J., Rubio-Ramrez, J.F., Sargent, T.J., Watson, M.W., 2007. ABCs (and Ds) of understanding VARs. Am. Econ. Rev. 97 (3), 1021-1026.

Fratzscher, M., Straub, R., 2013, October. Asset prices, news shocks, and the trade balance. J. Money, Credit, Bank. 45 (7), 1211-1451.

Fujiwara, I., Hirose, Y., Shintani, M., 2011, 02. Can news be a major source of aggregate fluctuations? A Bayesian DSGE approach. J. Money, Credit, Bank. 43 (1), $1-29$.

Jaimovich, N., Rebelo, S., 2008, December. News and business cycles in open economies. J. Money, Credit, Bank. 40 (8), 1699-1711.

Jaimovich, N., Rebelo, S., 2009, September. Can news about the future drive the business cycle? Am. Econ. Rev. 99 (4), 1097-1118.

Jermann, U., Quadrini, V., 2012. Macroeconomic effects of financial shocks. Am. Econ. Rev. 102 (1), 238-271.

Justiniano, A., Preston, B., 2010. Can structural small open-economy models account for the influence of foreign disturbances? J. Int. Econ. 81 (1), 61-74.

Kadiyala, K.R., Karlsson, S., 1997. Numerical methods for estimation and inference in Bayesian VAR-models. J. Appl. Econ. 12 (2), 99-132.

Khan, H., Tsoukalas, J., 2012, December. The quantitative importance of news shocks in estimated DSGE models. J. Money, Credit, Bank. 44 (8), 1535-1561. 
Kurmann, A., Otrok, C., 2009. News shocks and the slope of the term structure of interest rates. Am. Econ. Rev. 103 (6), 2612-2632.

Lutkepohl, H., 2007. New Introduction to Multiple Time Series Analysis. Springer Publishing Company, Incorporated, New York.

Mountford, A., Uhlig, H., 2009. What are the effects of fiscal policy shocks? J. Appl. Econ. 24 (6), 960-992.

Nam, D., Wang, J., 2015. The effects of surprise and anticipated technology changes on international relative prices and trade. . Tech. rep.

Pavlov, O., Weder, M., 2013. Countercyclical markups and news-driven business cycles. Rev. Econ. Dyn. 16 (2), 371-382.

Pinter, G., Theodoridis, K., Yates, T., 2013. Risk news shocks and the business cycle. mimeo
Schmitt-Grohe, S., Uribe, M., 2003. Closing small open economy models. J. Int. Econ. 61 (1), 163-185.

Schmitt-Grohé, S., Uribe, M., 2012. What's news in business cycles. Econometrica 80 (6), 2733-2764.

Theodoridis, K., Zanetti, F., 2013. News and labor market dynamics in the data and in matching models. mimeo

Uhlig, H., 2005. What are the effects of monetary policy on output? Results from an agnostic identification procedure. J. Monet. Econ. 52 (2), 381-419.

Walentin, K., 2012. Expectation driven business cycles with limited enforcement. Sveriges Riksbank Working Paper Series 229. Sveriges Riksbank. 